\title{
Comparative Studies of Nutritional, Microbial and Organoleptic Properties of Different Indigenous Dried Fish from Local Market in Bangladesh
}

\author{
Md. Masud Ranaa, Subhash Chandra Chakrabortyb, Abu Saeidc,* \\ a Department of Fishing and Post Harvest Technology, Sher-e-Bangla Agricultural University, Dhaka, Bangladesh \\ b Department of Fisheries Technology, Bangladesh Agricultural University, Mymensingh, Bangladesh \\ c Department of Food Engineering, NPI University of Bangladesh, Manikganj, Bangladesh
}

\section{ART I CLE I N F O}

Received: 06 July 2019

Revised: 29 July 2019

Accepted: 15 September 2019

Available online: 18 September 2019

\section{K E Y W O R D S}

\section{Dried fish}

Proximate composition

Total plate count

TVB-N

Sensory evaluation

\begin{abstract}
A B S T R A C T
In this study, ten indigenous dried market fishes were selected to analyze the proximate composition, microbial analysis, and organoleptic properties. Proximate compositions were found to be varied among the species. Moisture content ranged from $15.66 \%$ to $35.50 \%$, protein content ranged from $42.06 \%$ to $65.78 \%$, lipid content varied from $4.20 \%$ to $13.03 \%$ and ash content ranged of $5.28 \%$ to $18.60 \%$. The results of TVB-N in different fish species ranged from $11.15 \mathrm{mg} / 100 \mathrm{~g}$ to $18.33 \mathrm{mg} / 100 \mathrm{~g}$ with highest in Puti (Puntius sophore) whereas lowest in Chanda (Chanda ranga) species. The bacterial load of dried fish species ranged from $3.13 \times 10^{7}$ to $3.67 \times 10^{8}$ (CFU/gm) with highest in Katchki (Corica soborna) and lowest in Puti (Puntius sophore). The sensory evaluation results revealed that Chapila (Gudusia chapra) is superior among the other dried fish species with color, flavor and appearance aspect. Overall, Chanda (Chanda ranga) was the better quality regarding all parameter among other dried fish species except protein content highest in Churi (Trichiurus lepturus) which was significantly different $(\mathrm{P} \leq 0.05)$ from Chanda (Chanda ranga) species.
\end{abstract}

\section{GRA P H I CAL A B S TRACT}

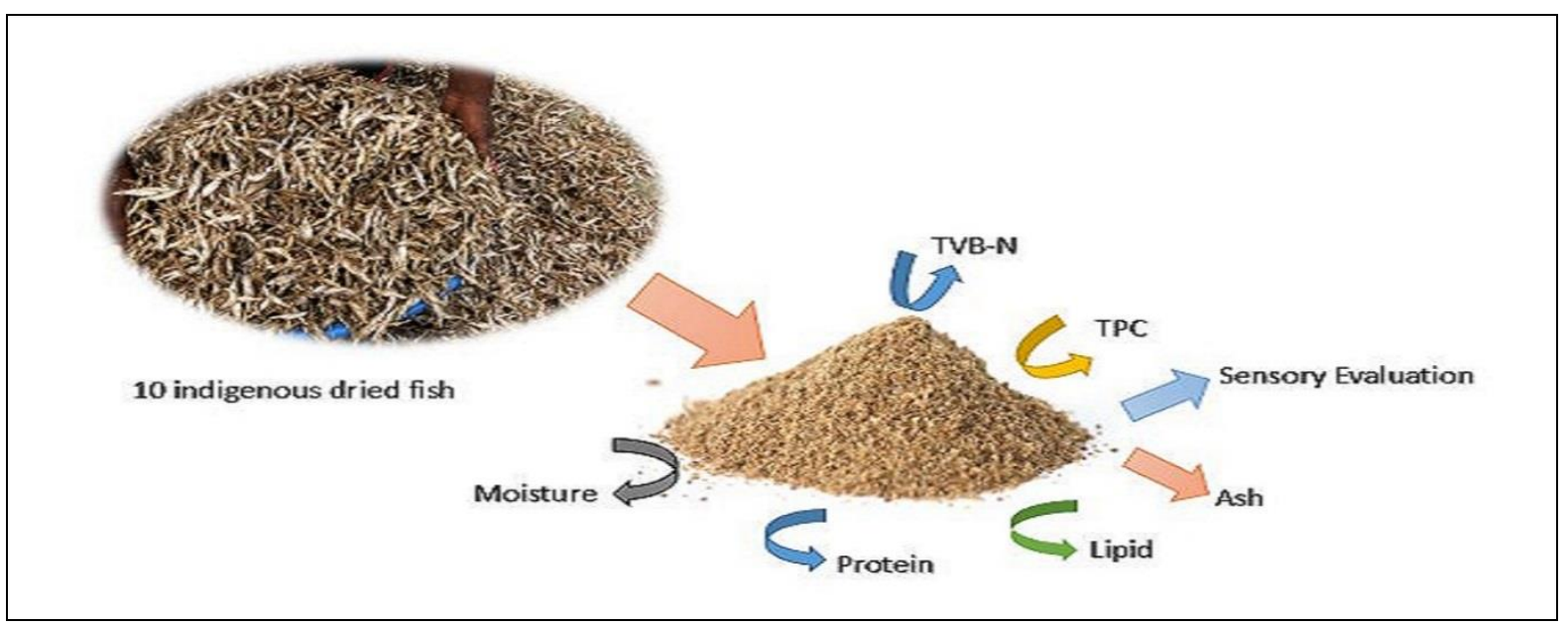

* Corresponding author's E-mail address: saeidfpp.hstu@gmail.com 


\section{Introduction}

Fish is one of the leading sources of animal protein and valuable in the diet because they provide a good quantity (70\% or more) of protein with high biological value, particularly sulphur containing amino acids [1]. The chemical composition of fish flesh including moisture, protein, lipid, ash, carbohydrate and other nutrients like mineral as well as vitamin [2] have the largest impact on the nutritive value, the functional properties, the sensory quality and the storage stability of meat [3]. They possess significant role in nutrition, income, employment and foreign currency earning of the country. Bangladesh earns a significant amount of foreign currency by exporting dried fish and fishery products which ranks third in the export item of fish and fishery products [4]. Bangladesh earned about Taka 3.71 core as foreign currency by exporting about 272 tons of dried fish and fishery products in 2013-2014 [5].

The dried fishery products are prepared from a large number of fish species including marine fish and fresh water fish. Small indigenous fishes are vital because they are valuable source of macro and micronutrients and play a crucial role to provide essential nutrients for the people of Bangladesh [6]. Small indigenous fish like mola, chapila, punti, chanda, batashi possess high nutritional value in terms of proteins and vitamins which are not commonly available from other foods [1].

Dried fish is considered one of the most vital animal protein sources and other essential nutrients component for the maintenance of a healthy body [7]. Moreover, dried fish was highly preferred by the Bangladeshi people of northeastern, central, and coastal areas due to it characteristic taste and flavor. On wet basis, essential nutrients are higher in dried fish as compare to the fresh fishes [8]. The dried fishes are susceptible to the insect attack or sometime microbial spoilage as a result reducing the losses of quality or sometime unfit for consumption. Available reports from the literature suggested that the quality of majority of the traditional sun dried products available in the market are not satisfactory for human consumption and complaint by the consumers about their quality [9]. Therefore, there is a need to regularly monitoring quality and safety of dried fish which are available in the local market.

So, the study of better quality of dried fishes in terms of nutritional profile including protein, lipid, and ash have to be informed to the consumer. This information will help the people to buy good quality of dried fishes and also will increase the consciousness of the people regarding the quality and safety aspect. The purpose of this study was to investigate the various quality parameter of different dried fish species in Bangladesh those included proximate composition, microbial analysis, organoleptic properties and so on.

\section{Experimental}

\section{Materials and methods}

\section{Sample collection and preparation}

Different indigenous dried fishes (whole) as Mola (Amblypharyngodon mola), Chapila (Gudusia chapra), Batashi (Pseudeutropius atherinoides), Puti (Puntius sophore), Tengra (Mystus tengara), Katchki (Corica soborna), Churi (Trichiurus lepturus), Taki (Channa punctatus), Loita (Harpadon nehereus) and Chanda (Chanda ranga) were purchased from different market of Dhaka city in Bangladesh. After that, the sample were packed in a polyethylene bag weighed $250 \mathrm{~g}$ each and sealed. Then each packet were carried out in the Post-Harvest Technology Laboratory of Sher-e-Bangla Agricultural University, Dhaka and stored at room temperature. Then the samples were grounded with blender (Model: Miyako 320) and powder of each sample was 
sieving (mesh size $20 \mu \mathrm{m}$ ) then stored in amber plastic bottle respectively for further analysis.

\section{Proximate composition analysis}

\section{Determination of moisture content}

AOAC [10] method was used to determine the moisture content of dried fish. Dried fish powder (5 g) was taken in a clean, dry and pre-weighted crucible. Then the crucible was transferred to oven (Model: BST/HAO-1122) and dried at $105^{\circ} \mathrm{C}$ for 16 hours. After that it was cooled at desiccator and weighed. Again it was transferred to oven and dried until a constant weight was obtained. Finally it was cooled and weighed. Moisture Content was calculated using the following formula:

$$
\% \text { Moisture }=\frac{\mathrm{W}_{1}-\mathrm{W}_{2}}{\mathrm{~W}} \times 100
$$

Here,

$\mathrm{W}_{1}=$ weight of sample with crucible

$\mathrm{W}_{2}=$ weight of dried sample with crucible

$\mathrm{W}=$ weight of sample

\section{Determination of Protein Content}

AOAC [10] method was used with some modification to determine the protein content $\left(\mathrm{N}_{2}\right)$ of the dried fish powder by Kjeldahl apparatus (Model: Kjeldahl ESEL 300 MI). Usually three stages are used to determine protein content. These stages are given below:

\section{Digestion}

Dried fish powder $(1 \mathrm{~g})$, Selenium powder (1 g), $\mathrm{CuSO}_{4}(0.1 \mathrm{~g}), \mathrm{K}_{2} \mathrm{SO}_{4}(10 \mathrm{~g})$ were taken into a volumetric flask. Then $25 \mathrm{ml}$ of $\mathrm{H}_{2} \mathrm{SO}_{4}$ (conc.) was added. After that the volumetric flask was heated at $100{ }^{\circ} \mathrm{C}$ for $3 \mathrm{hr}$. and cooled for 20 minute at room temperature.
Distillation

After digestion $300 \mathrm{~mL}$ of distilled water and $125 \mathrm{~mL}$ of $40 \% \mathrm{NaOH}$ were added to the volumetric flask. $25 \mathrm{~mL}$ of $4 \%$ boric acid solution and 2-3 drops mixed indicator were taken in a conical flask. The volumetric flask was connected with one end of the condenser and the conical flask was connected with other end. The volumetric flask was heated continuously until the conical flask was filled to $150 \mathrm{~mL}$.

\section{Titration}

The conical flask was disconnected and was taken for titration. Titrated against $0.2 \mathrm{~N}$ of $\mathrm{H}_{2} \mathrm{SO}_{4}$ solution. The end point was indicated by orange color.

i) Calculation for $\mathrm{N}_{2}$ content:

$\%$ of $\mathrm{N}_{2}=$ Burette reading $\times$ Normality of $\mathrm{H}_{2} \mathrm{SO}_{4}$ $\times$ ml equivalent of $N_{2}$

Here;

Normality of $\mathrm{H}_{2} \mathrm{SO}_{4}=0.2 \mathrm{~mL}$ equivalent of $\mathrm{N}_{2}$ $=1.4$

i) Calculation for protein content:

$$
\% \text { Protein }=\% \text { of } \mathrm{N}_{2} \times \text { Protein factor }
$$

Here;

Protein factor $=6.25$

\section{Determination of lipid content}

AOAC [10] method was used with slight modification to determine the lipid content. Dried fish powder ( $5 \mathrm{~g}$ ) was taken into the thimble. Then the thimble was attached to the Soxhlet apparatus (Model: SZF-06A/SZF-06C) which was attached with a round bottom flask containing $200 \mathrm{~mL}$ ether. The lipid was extracted for 16 hours. After that ether was evaporated at $80^{\circ} \mathrm{C}$ until the flask completely 
dried. Lipid content was calculated by following formula:

$$
\% \text { Fat }=\frac{\mathrm{W}_{1}-\mathrm{W}_{2}}{\mathrm{~W}} \times 100
$$

Here,

$\mathrm{W}_{1}=$ weight of evaporated flask with sample

$\mathrm{W}_{2}=$ weight of empty flask

$\mathrm{W}=$ weight of sample

\section{Determination of ash content}

AOAC [10] method was used to determine the total ash content. Dried fish powder (5 g) was weighed and transferred into a clean, dry and pre-weighted crucible. Then the crucible was kept into muffle furnace (Model: ACMAS ATI-118-A) at $550^{\circ} \mathrm{C}$ for 6 hours. It was cooled at desiccator and weighed. The ash content was calculated by the following equation:

$$
\% \text { Ash }=\frac{\mathrm{W}_{1}-\mathrm{W}_{2}}{\mathrm{~W}} \times 100
$$

Here,

$\mathrm{W}_{1}=$ weight of ash with crucible

$\mathrm{W}_{2}=$ weight of empty crucible

$\mathrm{W}=$ weight of sample

Determination of total volatile base nitrogen (TVB-N)

Total volatile base nitrogen (TVB-N) was determined according to the standard method described by Pravakar et al. [11] with some modifications. $10 \mathrm{~g}$ of dried fish powder mixed with $90 \mathrm{~mL}$ of $6 \%$ perchloric acid and homogenized for two minutes in cooled condition. After that, $100 \mathrm{ml}$ of extract with 4-6 drops phenolphthalein was taken in a Kjeldahl flask and then some glass beads was added. Then $10 \mathrm{~mL}$ of $40 \% \mathrm{NaOH}$ was also added to the flask. After that the flask placed in the distillation chamber and distillation was continued for 15 minutes. Then the distillate was collected in the conical flask containing $50 \mathrm{ml}$ of $3 \% \mathrm{H}_{3} \mathrm{BO}_{3}$. One drop of mixed indicator was added to it. Distillation confirmed through changing the color of mixed indicator from violet to greenish. After distillation, the collected distillate was titrated with $0.01 \mathrm{~N}$ standard $\mathrm{HCl}$ and regarding the violet color of mixed indicator confirms the end point. The TVB$\mathrm{N}$ was calculated using the following equation:

$$
\begin{aligned}
& \text { TVB }-\mathrm{N}\left(\frac{\mathrm{mg}}{100 \mathrm{~g}}\right) \\
& =\frac{\mathrm{ml} \text { of titrant used } \times 0.014 \times \text { Normality of titrant }}{\text { Weight of sample }(\mathrm{g})} \\
& \times 100
\end{aligned}
$$

\section{Microbial analysis}

Total bacterial count of the samples was done by Standard Plate Count (SPC) method shown in Figure 1, ISO [12].

No. of bacteria per gram of the dried fish sample (CFU/g) was calculated by using the following formula:

$$
\begin{aligned}
& \text { Total plate count } \\
& \left.\qquad \frac{\mathrm{CFU}}{\mathrm{g}}\right) \\
& =(\text { No. of colonies on petridish } \\
& \times 10 \times \text { dilution factor } \\
& \times \text { weight of sample solution }) \\
& \\
& /(\text { Weight of sample }(\mathrm{g}))
\end{aligned}
$$

\section{Organoleptic Properties Analysis}

Fifteen trained members were selected from the University community. Randomly, the samples were presented. Grounded dried fishes were evaluated organoleptically for color, flavor and appearance according to the hedonic scale of nine points ( $9=$ like extremely to1 = dislike extremely), as reported by Roy et al. [13]. 


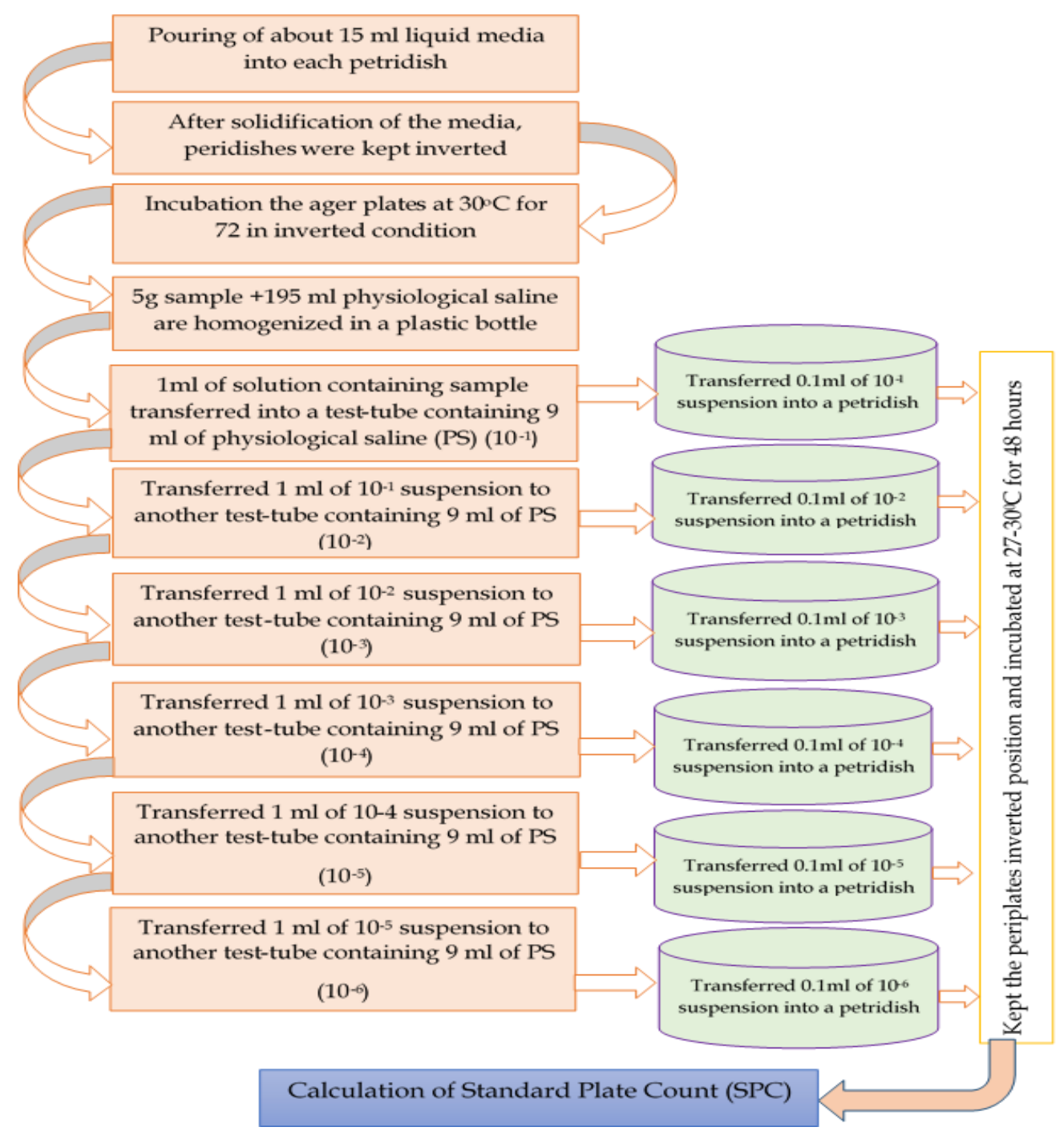

Figure 1. Schematically showing the standard plate count method using plate count agar medium

\section{Statistical analysis}

Data were analyzed statistically using the statistical software $\mathrm{R}$ (windows version 3.5.1).The mean values $( \pm S D)$ were compared by following the DMRT (Duncan Multiple Range Test) at 5\% level of significance. All measurements were carried out in triplicate for each of the sample.

\section{Results and Discussion}

The proximate compositions of different dried fish species are shown in Table 1 . The moisture content of different dried fish species varied between $15.66 \%$ to $35.50 \%$.
The highest moisture content in Taki species was $35.50 \%$ whereas lowest in chanda was $15.66 \%$. Our result is closely related to some previous studies was carried out by Hasan et al. [14] who found that the moisture content of dried fish was $13.71 \%$ to $27.33 \%$. These values are higher than the work of Flowra and Tumpa [3] who found the moisture content of five different dried fish species varies from $12.13 \%$ to $18.18 \%$. Faturoti [15] showed that the gutted dried fish samples of African catfish (Clarias nigrodigitus) had a chemical composition of 6.27 to $10.92 \%$ moisture. According to Hossain et al., [4] who reported that sundried Rohu fish contained $10.30 \%$ moisture. 
Table 1. Proximate composition of different dried fish species

\begin{tabular}{ccccc} 
Dried fish & \multicolumn{4}{c}{ Proximate composition } \\
Species & Moisture (\%) & Protein (\%) & Lipid (\%) & Ash (\%) \\
Mola & $24.85 \pm 0.97^{\mathrm{c}}$ & $48.94 \pm 0.26^{\mathrm{c}}$ & $10.06 \pm 0.20^{\mathrm{b}}$ & $16.12 \pm 0.27^{\mathrm{a} b}$ \\
Puti & $25.13 \pm 0.45^{\mathrm{c}}$ & $48.82 \pm 0.87^{\mathrm{c}}$ & $09.84 \pm 0.89^{\mathrm{b} c}$ & $16.11 \pm 0.90^{\mathrm{a}} \mathrm{b}$ \\
Batashi & $27.05 \pm 1.90^{\mathrm{bc}}$ & $45.80 \pm 2.96^{\mathrm{d}}$ & $11.80 \pm 0.60^{\mathrm{a}}$ & $15.00 \pm 0.88^{\mathrm{b} c}$ \\
Tengra & $27.52 \pm 0.82^{\mathrm{bc}}$ & $43.20 \pm 0.26^{\mathrm{e}}$ & $12.84 \pm 0.28^{\mathrm{a}}$ & $15.22 \pm 1.95^{\mathrm{bc}}$ \\
Chapila & $27.32 \pm 1.12^{\mathrm{bc}}$ & $49.60 \pm 0.51^{\mathrm{c}}$ & $08.76 \pm 1.92^{\mathrm{bc}}$ & $14.31 \pm 1.83^{\mathrm{bc}}$ \\
Katchki & $28.20 \pm 2.11^{\mathrm{b}}$ & $49.84 \pm 2.64^{\mathrm{c}}$ & $09.15 \pm 1.13^{\mathrm{bc}}$ & $12.63 \pm 1.62^{\mathrm{c}}$ \\
Churi & $19.92 \pm 2.12^{\mathrm{d}}$ & $65.78 \pm 1.20^{\mathrm{a}}$ & $09.02 \pm 0.89^{\mathrm{bc}}$ & $05.28 \pm 1.18^{\mathrm{e}}$ \\
Taki & $35.50 \pm 1.30^{\mathrm{a}}$ & $42.06 \pm 1.46^{\mathrm{e}}$ & $04.20 \pm 0.48^{\mathrm{d}}$ & $18.24 \pm 2.14^{\mathrm{a}}$ \\
Loita & $28.96 \pm 1.10^{\mathrm{b}}$ & $55.56 \pm 0.62^{\mathrm{b}}$ & $08.06 \pm 0.78^{\mathrm{c}}$ & $07.96 \pm 1.92^{\mathrm{d}}$ \\
Chanda & $15.66 \pm 1.33^{\mathrm{e}}$ & $50.53 \pm 1.55^{\mathrm{c}}$ & $13.03 \pm 1.03^{\mathrm{a}}$ & $18.60 \pm 0.98^{\mathrm{a}}$ \\
\hline
\end{tabular}

Mean \pm SD (Three determinations)

a-e Mean followed by different superscript in each column are significantly different $(\mathrm{P} \leq 0.05)$

According to Hasan et al., [17] who observed $13.71 \%$ to $26.42 \%$ of moisture in three small dried fishes which are known as small indigenous species (SIS). The findings of Hussain et al. [18] the moisture content varied over a large range from 12.3\%-54\%. Azam et al. [19] studied biochemical assessment of fourteen selected dried fish and observed that moisture content ranging from 18.23-23.61\%. Flowra and Tumpa [3] conducted an investigation on seasonal variation of biochemical composition in batashi fish (Clupisoma atherinoides) found moisture content around 3\%.The variation in moisture content of dried fish depends on seasonal variation, fish species and methods of drying. Moisture content varied in the dried fish might be the effect of the different drying methods [8]. It has been shown that the moisture content significantly different among the fish species.

However, the protein content of different dried fish ranged from $42.06 \%$ to $65.78 \%$ (Table 1). The highest values of protein found in Churi and lowest in Taki species. This values were supported to the work of Hasan $e t$ al. [14] who found that the protein content of dried fish species varied from $44.72 \%$ to $60.33 \% .44 .72 \%$ to $60.33 \%$ of protein found by Hasan et al., [17] in different small dried fish species. Azam et al. [19] reported the biochemical assessment of fourteen selected dried fish and found the protein content varied between 40.69- 66.52\%. Faturoti [15] showed that the gutted dried fish samples of African catfish (Clarias nigrodigitus) had a range of crude protein was 55.02 to $63.05 \%$. Rasul et al. [8] reported that the protein content in solar dried silver carp was $68.41 \%$ this value is higher than that our values. Sultana et al., [16] reported that sun dried fish species contained $60 \%$ to $80 \%$ protein. The variation in protein content is due mainly in species variation [1].

On the other hand, the lipid content of different dried fish species varies from $4.20 \%$ to $13.03 \%$ with highest in Chanda and lowest in Taki (Table 1). This values were supported according to the findings of Hasan et al. [14] who found that the lipid content of dried fish species from $8.91 \%$ to $18.07 \%$. These values within the range according to the work of Flowra and Tumpa [3] they obtained lipid content ranges of $5.38 \%$ to $15.86 \%$ from different selected dried fish. The more or less close result found by Azam et al. [19] observed that fat content was in fourteen selected dried fish range of $7.1 \%$ to $26.13 \%$. The lipid content in batashi fish was 3\% reported Flowra et al. [20] this value was lower than 
that we did. According to the report of Nurullah et al., [21] the lipid content of solar dried SIS (A. mola, O. cotio cotio, P. atherinoides, M. vitatus and G. chapra) varied from 14.10 to $16.26 \%$. The lipid content significantly different from fish species. Thelipid content may vary species to species and methods of extraction might be the causes of this variation.

The ash content of different dried fish species ranged from $5.28 \%$ to $18.60 \%$ with lowest value in Churi and and highest value in Taki (Table 1). This values almost similar with the work of Azam et al. [19] who found ash content in dried fish ranged between 5.08$12.14 \%$. Our result also support the findings of Nurullah et al., [21] who found the ash content of different dried fish species varies from $9 \%$ to $19.32 \%$. Furthermore, the obtained ash content is lower as compared to the work of Islam et al. [22] who found the ash content ranged of $20.14-24.40 \%$ in dried Mola and Taki respectively. Those values more or less similar than that of $11.00 \%$ to $14.63 \%$ [14]. The ash content of different dried fish species was significantly different $(\mathrm{P} \leq 0.05)$.

The total volatile base nitrogen (TVB-N) values of the different dried fish species are shown in Figure 2. The results of TVB-N in different fish species ranged from 11.15 $\mathrm{mg} / 100 \mathrm{~g}$ to $18.33 \mathrm{mg} / 100 \mathrm{~g}$ with higher in Puti whereas lower in Chanda species. Our result of TVB-N were supported by the work ofIslam et al. [23] who found the TVB-N in the dried Mola species prepared using solar or rotary dryer ranged from 10.64 to 20.36 $\mathrm{mg} / 100$ g. Furthermore, obtained values of TVB-N lower than the traditionally dried marine fish samples ranged between 28.46 to $42.88 \mathrm{mg} / 100 \mathrm{~g}$ [9]. However, TVB-N values of all the samples were found lower than the recommended value of $100-200 \mathrm{mg} / 100 \mathrm{~g}$ for variety of salted and dried products [23]. It has been reported that the TVB-N value of dried tilapia fillets ranged between 44.27 and $64.39 \mathrm{mg} / 100 \mathrm{~g}$ of muscle [24]. It is likely to expect low TVB-N values of dried products because if the limit exceed the dried fish product can be considered to be spoiled [9].

The total plate count expressed in colony forming unit (CFU/gm) and the values of different dried fish species has presented in the Table 2. The bacterial load of dried fish species ranged from $3.13 \times 10^{7}$ to $3.67 \times 10^{8}$ (CFU/gm) with highest in Katchki and lowest in Puti. Our result is closely related the work of Hasan et al. [14] who found he bacterial load of traditional dried SIS products ranged from $1.43 \times 10^{8} \mathrm{CFU} / \mathrm{g}$ to $2.89 \times 10^{8} \mathrm{CFU} / \mathrm{g}$.
Figure 2. Total volatile base nitrogen (TVB-N) content of different dried fish species

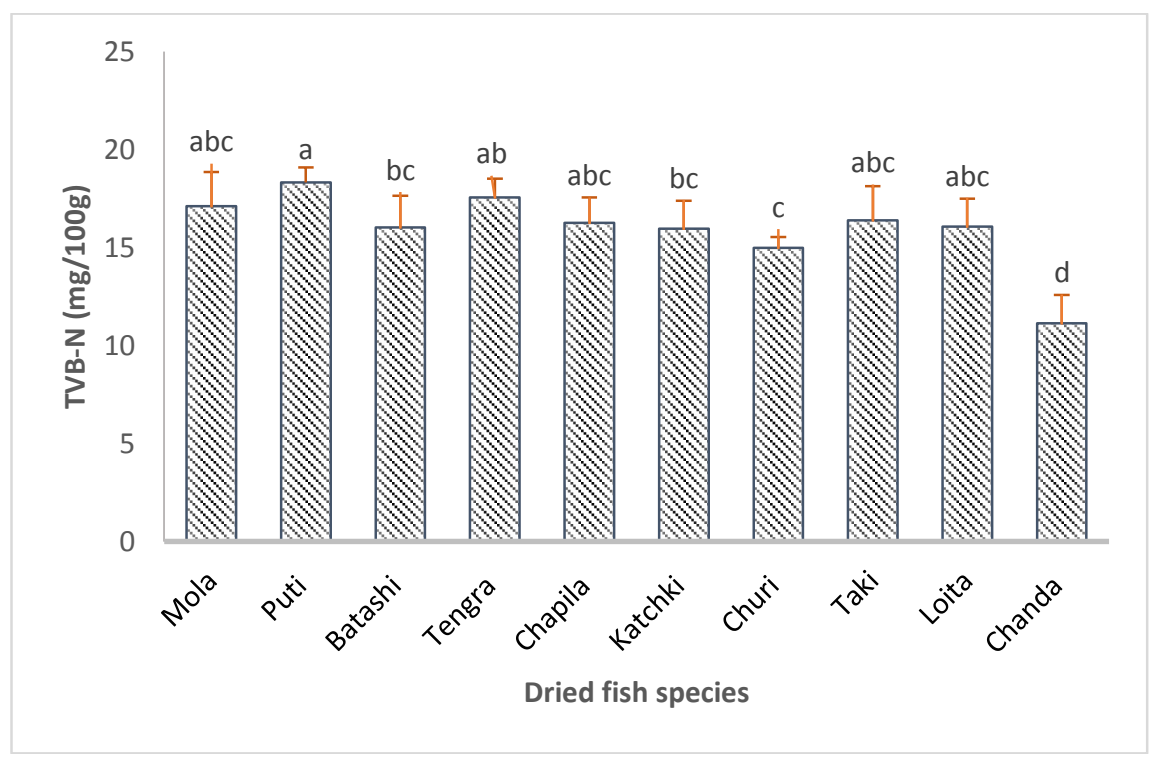


Table 2. Total plate count for the different dried fish species

\begin{tabular}{ccc} 
Dried fish species & Total plate count $(\mathrm{CFU} / \mathrm{gm})$ & Log $(\mathrm{CFU} / \mathrm{gm})$ \\
Mola & $1.87 \times 10^{8}$ & 8.26 \\
Puti & $3.13 \times 10^{7}$ & 7.50 \\
Batasi & $3.10 \times 10^{8}$ & 8.49 \\
Tengra & $1.73 \times 10^{8}$ & 8.24 \\
Chapila & $3.60 \times 10^{8}$ & 8.56 \\
Katchki & $3.67 \times 10^{8}$ & 8.56 \\
Churi & $4.07 \times 10^{7}$ & 7.61 \\
Taki & $1.97 \times 10^{8}$ & 8.29 \\
Loita & $2.43 \times 10^{8}$ & 8.39 \\
Chanda & $3.33 \times 10^{7}$ & 7.52 \\
\hline
\end{tabular}

Table 3. Sensory evaluation of different dried fish species

\begin{tabular}{cccc} 
Dried fish Species & Color & $\begin{array}{c}\text { Sensory evaluation } \\
\text { Flavor }\end{array}$ & Appearance \\
Mola & $3.20 \pm 1.01^{\mathrm{abc}}$ & $3.80 \pm 1.21^{\mathrm{abc}}$ & $3.87 \pm 1.41^{\mathrm{bc}}$ \\
Puti & $3.93 \pm 1.62^{\mathrm{a}}$ & $3.33 \pm 0.98^{\mathrm{bc}}$ & $4.00 \pm 1.31 \mathrm{~b}^{\mathrm{c}}$ \\
Batashi & $3.20 \pm 0.94^{\mathrm{abc}}$ & $4.20 \pm 1.26^{\mathrm{a}}$ & $4.47 \pm 0.83^{\mathrm{ab}}$ \\
Tengra & $2.93 \pm 0.96^{\mathrm{bc}}$ & $3.07 \pm 0.88^{\mathrm{c}}$ & $3.33 \pm 1.05^{\mathrm{c}}$ \\
Chapila & $4.00 \pm 1.41^{\mathrm{a}}$ & $3.80 \pm 1.21^{\mathrm{abc}}$ & $4.27 \pm 0.88^{\mathrm{ab}}$ \\
Katchki & $3.67 \pm 0.98^{\mathrm{abc}}$ & $3.20 \pm 0.86^{\mathrm{c}}$ & $3.87 \pm 0.88^{\mathrm{bc}}$ \\
Churi & $3.87 \pm 1.55^{\mathrm{ab}}$ & $4.07 \pm 1.22^{\mathrm{ab}}$ & $5.13 \pm 0.92^{\mathrm{a}}$ \\
Taki & $2.80 \pm 1.21^{\mathrm{c}}$ & $3.40 \pm 0.91^{\mathrm{abc}}$ & $3.33 \pm 1.11^{\mathrm{c}}$ \\
Loita & $3.60 \pm 1.12^{\mathrm{abc}}$ & $3.73 \pm 0.88^{\mathrm{abc}}$ & $3.60 \pm 1.59^{\mathrm{bc}}$ \\
Chanda & $3.93 \pm 1.09^{\mathrm{a}}$ & $3.07 \pm 0.70^{\mathrm{c}}$ & $3.93 \pm 1.16^{\mathrm{bc}}$ \\
\hline
\end{tabular}

Mean \pm Standard Deviation (SD)

a-c Mean followed by different superscript in each column are significantly different $(P \leq 0.05)$

Our obtained result much more higher as compare to the findings of Hossain et al. [4] who obtained result from some dried fish varied between $7.06 \times 10^{3} \mathrm{CFU} / \mathrm{g}$ to $5.58 \times 10^{4}$ CFU/g. Furthermore, Ito et al. [25] observed that the viable bacterial count of dried Sardine was $4.9 \times 10^{4} \mathrm{CFU} / \mathrm{g}$ and dried Jel fish was 1.0 $\times 10^{7} \mathrm{CFU} / \mathrm{g}$ respectively. According to Cho et al. [26] who reported the viable bacterial counts ranged from $10^{3}$ to $10^{7} \mathrm{CFU} / \mathrm{g}$ in dried fish. Although, a close relationship possess between the moisture content and the bacterial load in fish products. Mansur et al. [27] reported that, when the water content of fish fell below $25 \%$ of wet weight, bacterial action stopped and when the water content further reduced to $15 \%$, mold ceased to grow. But similar trend always not found. Dried fish products even with low moisture content stored under no protection against high humidity might be vehicle for bacteria responsible for food spoilage [4].

The organoleptic properties of different dried fish species were shown in the Table 3. The sensory profile evaluated in terms of color, flavor and appearance. The sensory score for color Chapila and Chanda was ahead from other species but for flavor Batashi and Churi got higher score follower by the others. On the other hand for appearance Churi had 
higher score followed by Batasi, Chapila and so. However sensory evaluation score for color, flavor and appreance significantly different among the dried fish species.

\section{Conclusion}

Dried fish is one of the most important sources of animal protein and other essential nutrients for the maintenance of a healthy body. Moreover, Bangladeshi people from northeastern, central, and coastal areas highly prefer this dried fish due to its characteristic taste and flavor. However, proximate composition, microbial analysis and organoleptic properties were investigated from different dried fish species. Overall, Chanda was the better quality regarding all parameters among other dried fish species except protein content highest in Churi which was significantly different $(\mathrm{P} \leq 0.05)$ from Chanda species. Finally, this study might be helpful for consumer to buy better quality dried fish available in the local market in Bangladesh.

\section{Acknowledgement}

We are grateful to the technical staff from the central laboratory of Sher-e-Bangla Agricultural University, Dhaka, Bangladesh and Fish nutrition laboratory Bangladesh Agricultural University, Mymensingh, Bangladesh for their kind cooperation.

\section{Disclosure statement}

No potential conflict of interest was reported by the authors.

\section{ORCID}

Abu Saeid (D): 0000-0003-3905-0833

\section{References}

[1] M.S.A. Mazumder, M.M. Rahman, A.T.A. Ahmed, M. Begum, M.A. Hossain, Int. J.
Sustain. Crop Prod., 2008, 3, 18-23.

[2] M.N. Islam, M.A.R. Joadder, Pak. J. Biol. Sci., 2005, 8, 532-536.

[3] A.F. Flowra, S.A. Tumpa, DAV Int. J. Sci., 2012, 1, 157-160.

[4] M.M. Hossain, M.D. Hossain, M.A. Noor, A.S.M.T. Haque, M.A. Kabir, J. Sylhet Agri. Univ., 2015, 2, 283-28.

[5] D.O.F, Fisheries statistics. Department of Fisheries, Ministry of Fisheries and Livestock, Government of People's Republic of Bangladesh, Dhaka, 2015.

[6] M. Zaman, M.N. Naser, A.T.M. Abdullah, N. Khan, Bangladesh J. Zool., 2014, 42, 251259.

[7] S.T. Arannilewa, S.O. Salawu, A.A. Sorungbe, B.B. Ola-Salawu, African J. Biotech., 2005, 4, 852-855.

[8] M.G. Rasul, B.C. Majumdar, F. Afrin, M.A.J. Bapary, A.K.M.A. Shah, Fishes, 2018, 3, 111.

[9] P.C. Paul, M.S. Reza, M.N. Islam, M. Kamal, Asian Food Sci. J., 2018, 5, 1-11.

[10] A.O.A.C., Official Method of Analysis. Association of Official Analytical Chemists. W. Horwitz (editor) 12 Edition. Washington, D.C., 2000.

[11] P. Pravakar, M.A. Mansur, M. Asadujjaman, World J. Zoolo., 2013, 8, 381-387.

[12] I.S.O., Recommendation of the meeting of subcommittee, International Organization for Standardization on meat and meat products. ISO/TC-36/Sc-6.The Netherlands, 1995, 10-18.

[13] M.C. Roy, M. Alam, A. Saeid, B.C. Das, M.B. Mia, M.A. Rahman, J.B. Eun, M. Ahmed, J. Food Process. Preserv., 2018, 42, e1341.

[14] M.M. Hasan, F.H. Shikha, M.I. Hossain, M. Kamal, M.N. Islam, M.A. Wahab, Bangladesh J. Fish. Res., 2006, 10, 73-84.

[15] E.O. Faturoti, Nutr. Reports Int., 1985, 30, 1395-1400.

[16] S. Sultana, S. Parween, M.A. Hossain, J. Life Sci., 2011, 6, 39-43.

[17] M.M. Hasan, F.H. Shika, M.I. Hossain, M. 
Kamal, M.N. Islam, M.A. Wahab, Bangladesh J. Fish. Res., 2006, 10, 73-84.

[18] M.M. Hussain, A. Karim, Z. Alam, M.M.S. Islam, A. Khan, A. Hossain, Bangladesh J. Zool., 1992, 20, 231-238.

[19] K. Azam, M.Z. Basher, M. Asaduzzaman, M.H. Hossain, M.Y. Ali, Univ. J. Zool. Rajshahi Univ., 2003, 22, 23-26.

[20] F.A. Flowra, A.S. Tumpa, M.T. Islam, Univ. J. Zool. Rajshahi Univ., 2012, 31, 9-11.

[21] M. Nurullah, M. Kamal, M.A. Wahab, M.N. Islam, M.S. Reza, S.H. Thilsted, M.A. Mazid, Bangladesh J. Fish. Res., 2006, 10, 63-72.

[22] M.T. Islam, S. Ahmed, M.A. Sultana, A.S. Tumpa, F.A. Flowra, Trend Fish. Res., 2013, 2, 14-17.
[23] M.J. Islam, M.S. Hossain, S. Mian, Int. J. Natr. Sci., 2012, 2, 43-48.

[24] F.M. Gamal, M.H. Eman, M.A. Latef, Glob. Vet., 2011, 7,138-148.

[25] H. Ito, A.M. Yusop, Agric. Biol. Chem., 1985, 49, 1047-1051.

[26] H.O. Cho, M.W. Bhyun, J.K. Kwon, Preservation of dried fish powder and mixed condiments by gamma irradiation. Division of Food in Sllation, Korea Advanced Energy Research Institute, Cheong Ryang, Seoul, Republic of Korea. IAEA-RC-341/4, 1998.

[27] M.A. Mansur, S. Rahman, M.N.A. Khan, M.S. Reza, Kamrunnahar, S. Uga, African J. Agric. Res., 2013, 8, 5149-5155.

How to cite this manuscript: Masud Rana, Subhash Chandra Chakraborty, Abu Saeid, Comparative Studies of Nutritional, Microbial and Organoleptic Properties of Different Indigenous Dried Fish from Local Market in Bangladesh, Adv. J. Chem. A, 2020, 3(3), 318327. 